\title{
Cryptosporidium animal species in Iran: a systematic review and meta-analysis
}

\author{
Mousa Motavalli Haghi ${ }^{1}$, Zohreh Khorshidvand ${ }^{1}$, Salman Khazaei ${ }^{2}$, Faezeh Foroughi-Parvar ${ }^{1}$, Hossein Sarmadian ${ }^{3}$, \\ Nastaran Barati ${ }^{4}$, Fariborz Etemadifar ${ }^{1}$ and Reza Ghasemikhah ${ }^{5^{*}}$ (i)
}

\begin{abstract}
Background: Cryptosporidiosis is an acute and short-term infection which can lead to severe diarrhea (intestinal cryptosporidiosis) associated with a persistent cough in the host with immune system defect. This systematic review and meta-analysis was conducted to estimate the prevalence of animal Cryptosporidium species and the corresponding epidemiological aspects in Iran.
\end{abstract}

Methods: In this study, all original research articles relating to the animal cryptosporidiosis in Iran were collected from reliable databases using keywords. A meta-analysis was conducted separately for each subgroup, and heterogeneity among the studies was performed using the $Q$ and $P$ tests. Furthermore, it should be noticed that the significance level in the statistical analysis with the Comprehensive Meta-analysis software was considered to be less than 0.05. Finally, meta-analysis results were shown in forest plot with a $95 \% \mathrm{Cl}$.

Results: In total, 4795 studies were included in the initial screening. Duplicated or non-original studies and the ones which did not meet our considered criteria were excluded from the list. Out of the 100 articles included in our first list for the meta-analysis, 40, 16, 13, 10, 9, 7, and 5 were done on cattle and calves, birds, dogs, sheep, rodents, camels, and horses, respectively. The prevalence rate of cryptosporidiosis among the birds, horses, rodents, camels, dogs, cattle, and sheep in Iran was estimated to be $7.5 \%, 19.5 \%, 20.8 \%, 8.4 \%, 4.9 \%, 14.4 \%$, and 9.1\%, respectively.

Conclusion: The different Cryptosporidium species have been found in different regions of Iran. Geographical region, climate, and domestic animals are considered as factors responsible for animal cryptosporidiosis prevalence in the area. Moreover, this parasite is zoonotic which causes disease in animals as well as humans which can result in economic loss.

Keywords: Cryptosporidium, Intestinal parasites, Animal, Systematic review, Iran

\section{Introduction}

Intestinal parasites are considered an important public health problem in humans and animals in developing and low-income countries [1-3]. Cryptosporidium is one of the most common intestinal protozoan parasites which is located in the phylum of Apicomplexa and causes cryptosporidiosis [2]. Cryptosporidium is spread easily in the environment

\footnotetext{
* Correspondence: ghasemikhah@yahoo.com; ghasemikhah@gmail.com ${ }^{5}$ Department of Parasitology and Mycology, School of Medicine, Arak University of Medical Sciences, Arak, Iran

Full list of author information is available at the end of the article
}

due to its simple transmission via contaminated water, air, and dust. Cryptosporidiosis is considered as a major economic problem in many countries including Iran, and there are annually numerous reports of this infection in immunocompromised and young children [2-5]. Different methods have been used to detect the protozoan parasite including the molecular diagnostic method which is considered one of the most useful diagnostic tools.

This method has identified up to 30 species and more than 50 genotypes of Cryptosporidium [6-8]. Different species of Cryptosporidium have been

(c) The Author(s). 2020 Open Access This article is licensed under a Creative Commons Attribution 4.0 International License, which permits use, sharing, adaptation, distribution and reproduction in any medium or format, as long as you give appropriate credit to the original author(s) and the source, provide a link to the Creative Commons licence, and indicate if changes were made. The images or other third party material in this article are included in the article's Creative Commons licence, unless indicated otherwise in a credit line to the material. If material is not included in the article's Creative Commons licence and your intended use is not permitted by statutory regulation or exceeds the permitted use, you will need to obtain permission directly from the copyright holder. To view a copy of this licence, visit http://creativecommons.org/licenses/by/4.0/. 
reported in various hosts including birds, horses, cattle, sheep, camels, rodents, and dogs. Cryptosporidium parvum, C. hominis, C. canis, C. felis, C. meleagridis, and $C$. muris were distinguished from gastrointestinal diseases as well as diarrhea in humans [9]. However, the infection typically occurs in a short-term and acute form in immunocompromised and HIV-positive individuals. In these cases, it tends to remain in the lower intestine for up to 6 weeks with severe diarrhea and persistent cough [9]. This protozoan could develop its life cycle in one host without the requirement of other animals as intermediate or reservoir hosts $[9,10]$. Despite the many studies which were conducted in Iran on investigating the prevalence of cryptosporidiosis in different animal hosts, these data have not shown the overall prevalence of animals in Iran. Since cryptosporidiosis causes irreversible economic damages to domestic animals, critical screening programs and epidemiological aspects should be considered by authorities. This systematic review and meta-analysis was conducted to estimate the prevalence of animal Cryptosporidium species and their epidemiological aspects in Iran.

\section{Materials and methods Study protocol}

The present systematic review focused on the estimates of the prevalence of animal Cryptosporidium species according to the PRISMA guidelines for systematic review and meta-analysis [11] (Supplementary 1).

\section{Search strategy}

In order to select the suitable articles for this study, all records since 1991 up to February 2018 were investigated using seven international databases in English including PubMed, Web of Science, Scopus, Science Direct, and Google Scholar search engine as well as national databases in Persian including Magiran (http://www.magiran.com/) and Scientific Information Database (SID) (http://www.sid.ir/). Furthermore, references of each article were screened manually, and the authors were contacted for additional references.

The databases screening was performed using the following keywords: prevalence, Cryptosporidium, cryptosporidiosis, animal Cryptosporidium, Cryptosporidium species, C. parvum, C.hominis, animal, cattle, calf, sheep, goat, camel, horse, rodent, bird, chicken, epidemiology, Iran, serology, PCR, and molecular (Box 1).
Box 1 Search strategy for MEDLINE (Mesh, Medical Subject Headings)

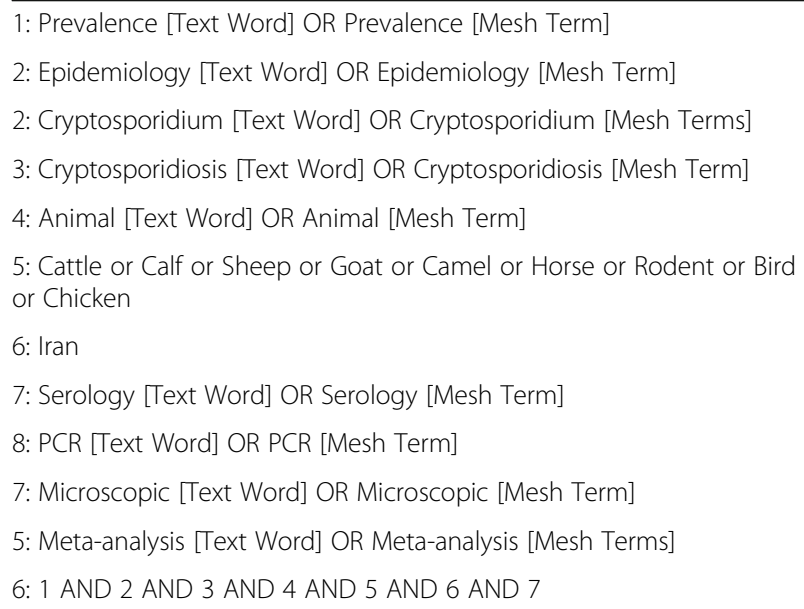

\section{Eligibility criteria}

All original descriptive studies which investigated the prevalence of Cryptosporidium in animals in Iran, both in English and Persian, were included in this study. Duplicates, qualitative studies, review articles, case reports, case series, and studies out of Iran or those performed on humans were excluded. Finally, articles with epidemiological parameters of interest were selected, and a total of 100 collected articles fulfilled the considered criteria.

\section{Quality assessment}

The scoring system based on the 8-item modified Newcastle Ottawa Scale (NOS) for non-randomized studies was used for assessing the quality of the studies. In this system, each question has a score between 0 and 1 , and the maximum point summation is 9 . Studies with point summation 5 or less, $6-7$, and 8-9 were considered low, moderate, and high quality, respectively [12].

\section{Screening and data extraction}

All records were evaluated based on their title and abstract and according to the inclusion and exclusion criteria by two researchers ( $\mathrm{MM}$ and $\mathrm{NB}$ ) independently. The kappa index showed an agreement of $91 \%$ between the findings of two researchers. The full-text version of the papers was obtained through library resources and online databases. Finally, the difference between records among the researchers was corrected by re-examining the articles. The agreement was reached by group discussion with a third researcher (SK).

Data extraction was conducted independently by two researchers (MM and $\mathrm{NB}$ ) and imported to the preprepared form. Data including authors, year of study, publication year, kind of animal, geographical area of the 
study, number of examined, number of positive, prevalence rate, and type of host were extracted from articles.

\section{Quality assessment studies}

The methodological quality of the studies was examined based on the guidelines of the Newcastle and Ottawa Statements [12]. This guideline sets the criteria for selecting people to study, comparing and accepting them, as well as exposure and consequences where a maximum of 9 stars can be allocated to each study. Studies with 7 stars or more are classified as highquality studies, and studies with 6 stars and less are considered as low-quality studies. Investigating the probability of an error in the results of the studies is performed separately by two researchers. The disagreement between the parties is resolved through negotiations.

\section{Data analysis}

The meta-analysis method was adopted to a $95 \%$ confidence interval (CI) in order to assess the pooled prevalence of Cryptosporidium infection in animals using the random effect model. Various subgroup analyses were separately conducted based on animal type and the associated species. Finally, meta-analysis results were displayed in forest plot (reported as effect estimates (ES) with a $95 \% \mathrm{CI}$ ). We also performed a sensitivity analysis to verify the stability of the data. In order to assess the sensitivity analysis, the effect estimate was estimated irrespective of one study at a time, and the robustness of the pooled estimate was assessed. Heterogeneity was calculated among the studies by the $Q$ and $I^{2}$ tests $[6,8]$. Cochran's $Q$ test $(Q$ statistic, $p<0.10)$ showed statistically significant heterogeneity, and $I^{2}$ statistic $\left(I^{2}>50 \%\right)$ indicates a large heterogeneity. Statistical analysis and data analysis were performed using the second version of the Comprehensive Meta-analysis software. The significance level was considered to be less than 0.05 .

\section{Results}

\section{Description of studies}

In total, 4795 studies were collected in the initial screenings from the published articles and their references in

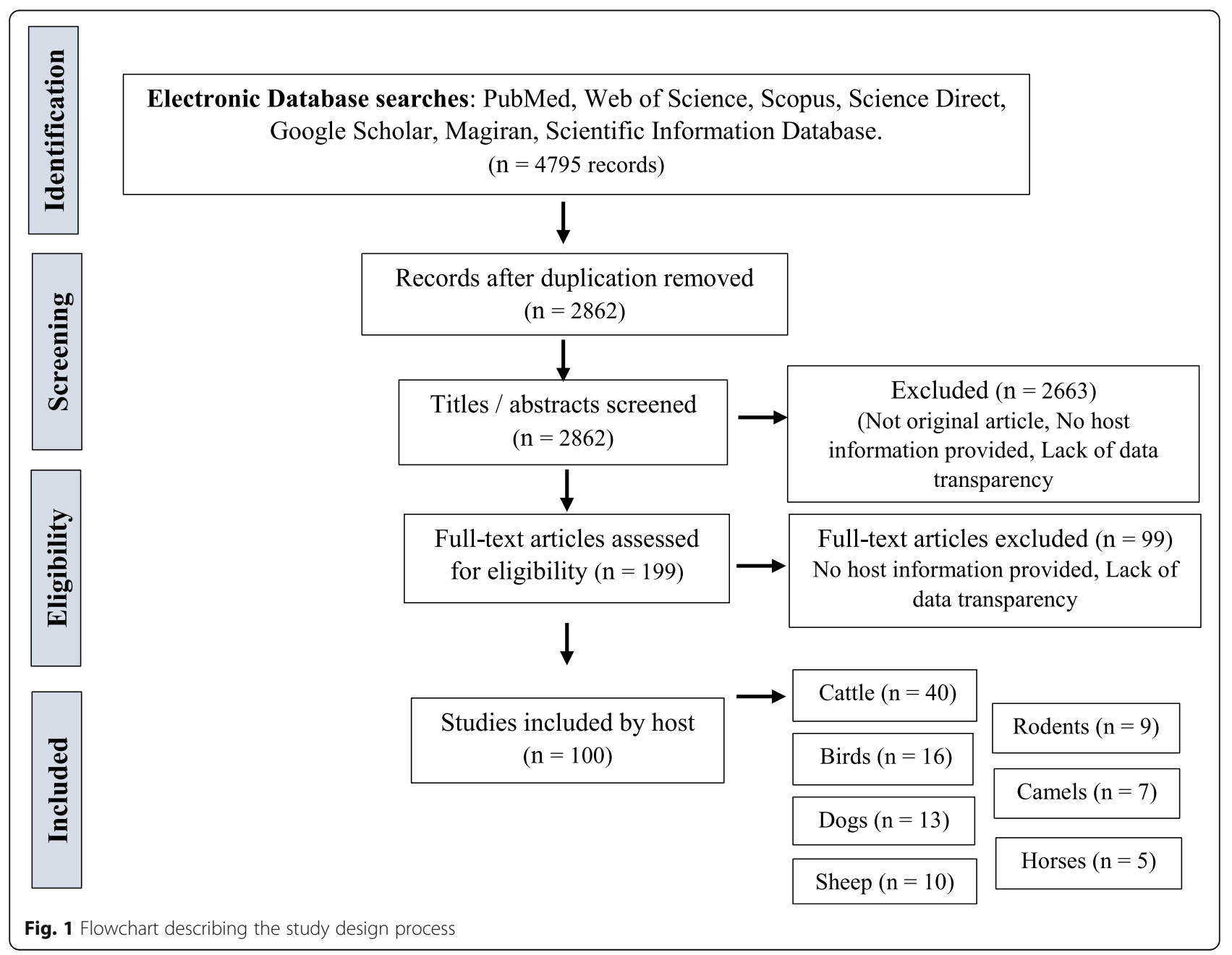


Table 1 Baseline characteristics of included studies

\begin{tabular}{|c|c|c|c|c|c|c|c|c|}
\hline First author & $\begin{array}{l}\text { Publication } \\
\text { year }\end{array}$ & Province & Animal & Samples & $\begin{array}{l}\text { Positive } \\
\text { samples }\end{array}$ & $\begin{array}{l}\text { Prevalence } \\
(\%)\end{array}$ & Species & $\begin{array}{l}\text { Laboratory } \\
\text { method }\end{array}$ \\
\hline Nouri [13] & 1991 & Lorestan & Sheep & 276 & 37 & 13.4 & Cryptosporidium spp. & Microscopic \\
\hline Rezaeian [14] & 1993 & Tehran & Sheep & 510 & 26 & 5.1 & Cryptosporidium spp. & Microscopic \\
\hline Fasihi Harandi [15] & 2006 & Kerman & Sheep & 434 & 60 & 13.8 & Cryptosporidium spp. & Microscopic \\
\hline Vahedi [16] & 2008 & Mazandaran & Lamb & 708 & 29 & 4.1 & Cryptosporidium spp. & Microscopic \\
\hline Heidari [17] & 2012 & Hamadan & Sheep & 220 & 19 & 8.6 & Cryptosporidium spp. & Microscopic \\
\hline Khezri [18] & 2013 & Kurdistan & Lamb & 850 & 87 & 10.2 & Cryptosporidium spp. & Microscopic \\
\hline Gharekhani [19] & 2013 & $\begin{array}{l}\text { Hamedan Esfahan, Yazd Fars, } \\
\text { Bushehr Mazandaran }\end{array}$ & Sheep & 1749 & 198 & 11.3 & Cryptosporidium spp. & Microscopic \\
\hline Shafieyan [20] & 2014 & Lorestan & Sheep & 345 & 20 & 5.8 & Cryptosporidium spp. & Microscopic \\
\hline Sadeghi [21] & 2015 & Kurdistan & Sheep & 180 & 11 & 6.1 & Cryptosporidium spp. & Microscopic \\
\hline Dalimi [6] & 2017 & Tehran & Sheep & 1300 & 22 & 1.7 & $\begin{array}{l}\text { C. andersoni, } C \text {. } \\
\text { parvum }\end{array}$ & Nested-PCR \\
\hline Radfar [22] & 2006 & Kerman & Calf & 291 & 63 & 21.6 & Cryptosporidium spp. & Microscopic \\
\hline Maleki [23] & 2006 & Lorestan & Cattle & 400 & 70 & 17.5 & Cryptosporidium spp. & Microscopic \\
\hline Parsa [24] & 2007 & Azerbaijan & Cattle & 300 & 16 & 5.3 & C. andersoni & Microscopic \\
\hline Azami [25] & 2007 & Isfahan & Cattle & 480 & 30 & 6.3 & Cryptosporidium spp. & Microscopic \\
\hline Azizi [26] & 2007 & Chaharmahl & Calf & 400 & 72 & 18 & Cryptosporidium spp. & Microscopic \\
\hline Yakhchali [27] & 2007 & Kurdistan & Cattle & 260 & 103 & 39.6 & Cryptosporidium spp. & Microscopic \\
\hline Keshavarz [28] & 2008 & Qazvin & Cattle & 272 & 51 & 18.8 & $\begin{array}{l}\text { C. andersoni, } C \text {. } \\
\text { parvum, C. bovis }\end{array}$ & PCR-RFLP \\
\hline \multirow[t]{2}{*}{ Mohamadi [29] } & 2008 & Ardabil & Cattle & 107 & 14 & 13.1 & C. andersoni & $\begin{array}{l}\text { Nested } \\
\text { PCR\&RFLP }\end{array}$ \\
\hline & & Ardabil & Cattle & 107 & 5 & 4.7 & C. parvum & $\begin{array}{l}\text { Nested } \\
\text { PCR\&RFLP }\end{array}$ \\
\hline Hassanpour [30] & 2008 & Azerbaijan & Calf & 482 & 31 & 6.4 & Cryptosporidium spp. & Microscopic \\
\hline Fotouhi [31] & 2008 & Kerman & Cattle & 412 & 78 & 18.9 & $\begin{array}{l}\text { C. andersoni, } C \text {. } \\
\text { parvum }\end{array}$ & Microscopic \\
\hline Vahedi [16] & 2008 & Mazandaran & Calf & 713 & 28 & 3.9 & Cryptosporidium. spp. & Microscopic \\
\hline Shayan [32] & 2008 & Tehran & Cattle & 173 & 64 & 37 & Cryptosporidium spp. & Microscopic \\
\hline \multirow[t]{2}{*}{ Davoudi [33] } & 2009 & Azerbaijan & Calf & 50 & 7 & 14 & Cryptosporidium spp. & Microscopic \\
\hline & & & Rat & & 40 & 80 & & \\
\hline Pirestani [34] & 2009 & Tehran & Calf & 573 & 69 & 12 & Cryptosporidium spp. & Microscopic \\
\hline Ranjbar [35] & 2009 & Mazandaran & Calf & 150 & 11 & 7.3 & Cryptosporidium spp. & Microscopic \\
\hline Fallah [36] & 2009 & Kurdistan & Calf & 412 & 35 & 8.5 & Cryptosporidium spp. & Microscopic \\
\hline Baghban [37] & 2009 & Kohkiluyeh & Calf & 80 & 37 & 46.3 & Cryptosporidium spp. & Microscopic \\
\hline $\begin{array}{l}\text { Nourmohamadzadeh } \\
\text { [38] }\end{array}$ & 2010 & Azerbaijan & Calf & 500 & 207 & 41.4 & Cryptosporidium spp. & Microscopic \\
\hline Safavi Afshari [39] & 2010 & Khorasan & Calf & 112 & 82 & 73.2 & Cryptosporidium spp. & Microscopic \\
\hline Ranjbar [40] & 2011 & Tehran & Calf & 200 & 35 & 17.5 & Cryptosporidium spp. & Microscopic \\
\hline Changizi [41] & 2011 & Semnan & Cattle & 200 & 21 & 10.5 & C. ryanae & Microscopic \\
\hline Bairami [42] & 2011 & Tehran & Cattle & 100 & 30 & 30 & Cryptosporidium spp. & PCR \\
\hline Heidarnegadi [43] & 2011 & Khuzestan & Cattle & 45 & 29 & 64.4 & Cryptosporidium spp. & Microscopic \\
\hline Ranjbar [44] & 2013 & Khorasan & Calf & 400 & 10 & 5.2 & Cryptosporidium spp. & Microscopic \\
\hline Ghadrdan [45] & 2011 & Semnan & Calf & 50 & 8 & 16 & Cryptosporidium spp. & Microscopic \\
\hline Heidari [46] & 2012 & Hamadan & Cattle & 477 & 76 & 15.9 & Cryptosporidium spp. & Microscopic \\
\hline Ranjbar [47] & 2012 & Khorasan & Calf & 170 & 19 & 11.2 & Cryptosporidium spp. & Microscopic \\
\hline
\end{tabular}


Table 1 Baseline characteristics of included studies (Continued)

\begin{tabular}{|c|c|c|c|c|c|c|c|c|}
\hline First author & $\begin{array}{l}\text { Publication } \\
\text { year }\end{array}$ & Province & Animal & Samples & $\begin{array}{l}\text { Positive } \\
\text { samples }\end{array}$ & $\begin{array}{l}\text { Prevalence } \\
\text { (\%) }\end{array}$ & Species & $\begin{array}{l}\text { Laboratory } \\
\text { method }\end{array}$ \\
\hline Jafari [48] & 2012 & Hamedan & Calf & 195 & 25 & 12.8 & Cryptosporidium spp. & Microscopic \\
\hline Asadpour [49] & 2013 & Khorasan & Calf & 300 & 45 & 15 & C. parvum & PCR-RFLP \\
\hline Mirzai [50] & 2013 & Azerbaijan & Cattle & 246 & 55 & 22.4 & $\begin{array}{l}\text { C. andersoni, C. } \\
\text { parvum }\end{array}$ & Microscopic \\
\hline Dalimi [51] & 2013 & Tehran & Cattle & 940 & 23 & 2.4 & C. andersoni & Nested PCR \\
\hline Shafieyan [20] & 2014 & Lorestan & Cattle & 430 & 39 & 9.1 & Cryptosporidium spp. & Microscopic \\
\hline Mojarad [52] & 2014 & Qazvin & Cattle & 158 & 26 & 16.5 & Cryptosporidium spp. & Microscopic \\
\hline Bahrami [53] & 2014 & Khuzestan & Calf & 90 & 41 & 45.6 & Cryptosporidium spp. & Microscopic \\
\hline Mahami oskouei [54] & 2014 & Ilam & Cattle & 217 & 8 & 3.7 & C. parvum & $\begin{array}{l}\text { Nested } \\
\text { PCR\&RFLP }\end{array}$ \\
\hline Mirzaghavami [55] & 2015 & Tehran & Cattle & 50 & 12 & 24 & Cryptosporidium spp. & Microscopic \\
\hline Saki [1] & 2017 & Khuzestan & Cattle & 240 & 5 & 2.1 & C. parvum & $\begin{array}{l}\text { Nested } \\
\text { PCR\&RFLP }\end{array}$ \\
\hline Mosallanejad [56] & 2010 & Khuzestan & Dog & 93 & 4 & 4.3 & C. parvum & ELISA \\
\hline Kake khani [57] & 2011 & Ilam & Dog & 112 & 8 & 7.1 & Cryptosporidium spp. & Microscopic \\
\hline Heidari [17] & 2012 & Hamadan & Dog & 210 & 8 & 3.8 & Cryptosporidium spp. & Microscopic \\
\hline Badrooj [58] & 2012 & Shiraz & Dog & 29 & 0 & 1.7 & Cryptosporidium spp. & PCR \\
\hline Beiromvand [59] & 2012 & Khorasan & Dog & 77 & 4 & 5.2 & Cryptosporidium spp. & Microscopic \\
\hline \multirow[t]{2}{*}{ Mirzaei [60] } & 2013 & Kerman & Dog & 548 & 11 & 2 & Cryptosporidium spp. & Microscopic \\
\hline & & & & 100 & 3 & 3 & Cryptosporidium spp. & Microscopic \\
\hline Gharekhani [61] & 2014 & Hamedan & Dog & 210 & 8 & 3.8 & Cryptosporidium spp. & Microscopic \\
\hline Arzamani [62] & 2016 & Khorasan & Dog & 32 & 1 & 3.1 & Cryptosporidium spp. & Microscopic \\
\hline Tavalla [63] & 2017 & Khuzestan & Dog & 350 & 43 & 12.3 & Cryptosporidium spp. & PCR \\
\hline Mohaghegh [64] & 2017 & Kermanshah & Dog & 301 & 72 & 23.9 & Cryptosporidium spp. & Microscopic \\
\hline Ranjbar [9] & 2018 & Isfahan & Dog & 140 & 3 & 2.1 & C. parvum & PCR \\
\hline Borji [65] & 2009 & Khorasan & Camel & 306 & 6 & 2 & Cryptosporidium spp. & Microscopic \\
\hline Behzadi [66] & 2009 & Isfahan & Camel & 103 & 39 & 37.9 & Cryptosporidium spp. & Microscopic \\
\hline Nazifi [67] & 2009 & Hormozgan & Camel & 65 & 11 & 16.9 & Cryptosporidium spp. & Microscopic \\
\hline Sazmand [68] & 2011 & Yazd & Camel & 300 & 61 & 20.3 & Cryptosporidium spp. & Microscopic \\
\hline Yakhchali [69] & 2012 & Azerbaijan & Camel & 170 & 17 & 10 & Cryptosporidium spp. & Microscopic \\
\hline Radfar [70] & 2012 & Kerman & Camel & 85 & 2 & 2.4 & C. parvum & ELISA \\
\hline Shahraki [71] & 2015 & Sistan & Camel & 184 & 1 & 0.5 & C. parvum & ELISA \\
\hline Hamedi [72] & 2003 & Hormozgan & Rat & 63 & 11 & 17.5 & Cryptosporidium spp. & Microscopic \\
\hline Shiraz i[73] & 2009 & Azerbaijan & Rat & 50 & 37 & 74 & Cryptosporidium spp. & Microscopic \\
\hline Davoudi [32] & 2010 & Azerbaijan & Rat & 50 & 40 & 80 & Cryptosporidium spp. & Microscopic \\
\hline Bahrami [74] & 2012 & Tehran & Rat & 77 & 21 & 27.3 & C. parvum & PCR-RFLP \\
\hline Borji [75] & 2013 & Khorasan & Hamster & 100 & 44 & 44 & Cryptosporidium spp. & Microscopic \\
\hline Mirzaghavami [56] & 2015 & Tehran & Rat & 180 & 23 & 12.8 & Cryptosporidium spp. & Microscopic \\
\hline Saki [1] & 2016 & Khuzestan & Rodent & 100 & 3 & 3 & C. parvum & $\begin{array}{l}\text { Nested } \\
\text { PCR\&RFLP }\end{array}$ \\
\hline Valipour [76] & 2016 & Khuzestan & Rat & 42 & 3 & 7.1 & Cryptosporidium spp. & Microscopic \\
\hline Mohebali [77] & 2017 & Azerbaijan & Rodent & 204 & 1 & 0.5 & Cryptosporidium spp. & Microscopic \\
\hline Banani [78] & 2000 & Fars & Chicken & 1522 & 125 & 8.2 & C. bailey & ELISA \\
\hline Mirzai [79] & 2008 & Kerman & Pigeon & 400 & 10 & 2.5 & Cryptosporidium spp. & Microscopic \\
\hline Behzadi [67] & 2009 & Isfahan & Ostrich & 75 & 21 & 28 & Cryptosporidium spp. & Microscopic \\
\hline
\end{tabular}


Table 1 Baseline characteristics of included studies (Continued)

\begin{tabular}{|c|c|c|c|c|c|c|c|c|}
\hline First author & $\begin{array}{l}\text { Publication } \\
\text { year }\end{array}$ & Province & Animal & Samples & $\begin{array}{l}\text { Positive } \\
\text { samples }\end{array}$ & $\begin{array}{l}\text { Prevalence } \\
(\%)\end{array}$ & Species & $\begin{array}{l}\text { Laboratory } \\
\text { method }\end{array}$ \\
\hline Norolahi Fard [80] & 2010 & Khorasan & Pigeon & 200 & 5 & 2.5 & Cryptosporidium spp. & Microscopic \\
\hline Shemshadi [81] & 2010 & Semnan & Broiler & 240 & 57 & 23.8 & Cryptosporidium spp. & Microscopic \\
\hline Haghbin [82] & 2010 & Mazandaran & Broiler & 300 & 39 & 13 & Cryptosporidium spp. & Microscopic \\
\hline Radfar [83] & 2011 & Khorasan & Pigeon & 102 & 3 & 2.9 & Cryptosporidium spp. & Microscopic \\
\hline Heidarnegadi [42] & 2011 & Khuzestan & Turkey & 22 & 11 & 50 & Cryptosporidium spp. & Microscopic \\
\hline Heidari [17] & 2012 & Hamadan & Poultry & 200 & 5 & 2.5 & Cryptosporidium spp. & Microscopic \\
\hline Hamidinejat [84] & 2014 & Lorestan & Chicken & 1000 & 7 & 0.7 & C. bailey & PCR-RFLP \\
\hline Hashemzade [85] & 2014 & Azerbaijan & Bird & 400 & 36 & 9 & Cryptosporidium spp. & Microscopic \\
\hline Hashemzade [86] & 2014 & Azerbaijan & Poultry & 400 & 21 & 5.3 & Cryptosporidium spp. & Microscopic \\
\hline Mirzaghavami [56] & 2015 & Tehran & Pigeon & 40 & 1 & 2.5 & Cryptosporidium spp. & Microscopic \\
\hline Shemshadi [87] & 2016 & Rasht & Duck & 30 & 5 & 16.7 & C. bailey & Microscopic \\
\hline Soltanialvar [88] & 2016 & Khuzestan & Turkey & 200 & 4 & 2 & Cryptosporidium spp. & Microscopic \\
\hline Larki [89] & 2017 & Khuzestan & Duck & 41 & 11 & 26.8 & Cryptosporidium spp. & Microscopic \\
\hline Naghibi [90] & 2002 & Khorasan & Horse & 300 & 80 & 26.7 & Cryptosporidium spp. & Microscopic \\
\hline Tavassoli [91] & 2005 & Azerbaijan & Horse & 221 & 35 & 15.8 & Cryptosporidium spp. & Microscopic \\
\hline Mirian [5] & 2010 & Tehran & Horse & 200 & 50 & 25 & Cryptosporidium spp. & Microscopic \\
\hline Heidari [17] & 2012 & Hamedan & Horse & 158 & 20 & 12.7 & Cryptosporidium spp. & Microscopic \\
\hline Ghadrdan [92] & 2012 & Khuzestan & Horse & 100 & 18 & 18 & Cryptosporidium spp. & Microscopic \\
\hline
\end{tabular}

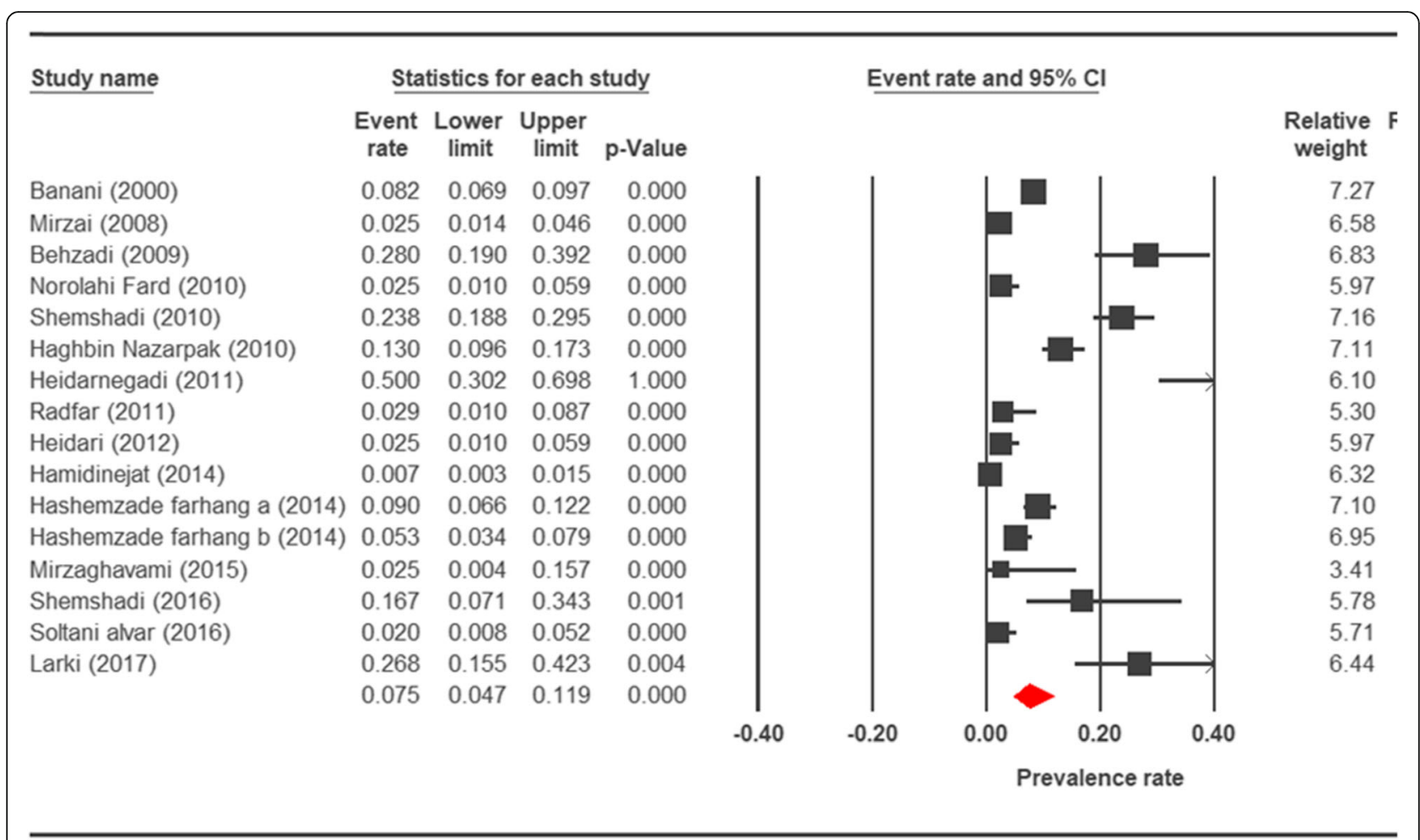

Fig. 2 Forest plot diagram showing the prevalence rate of Cryptosporidium infection in birds of Iran 


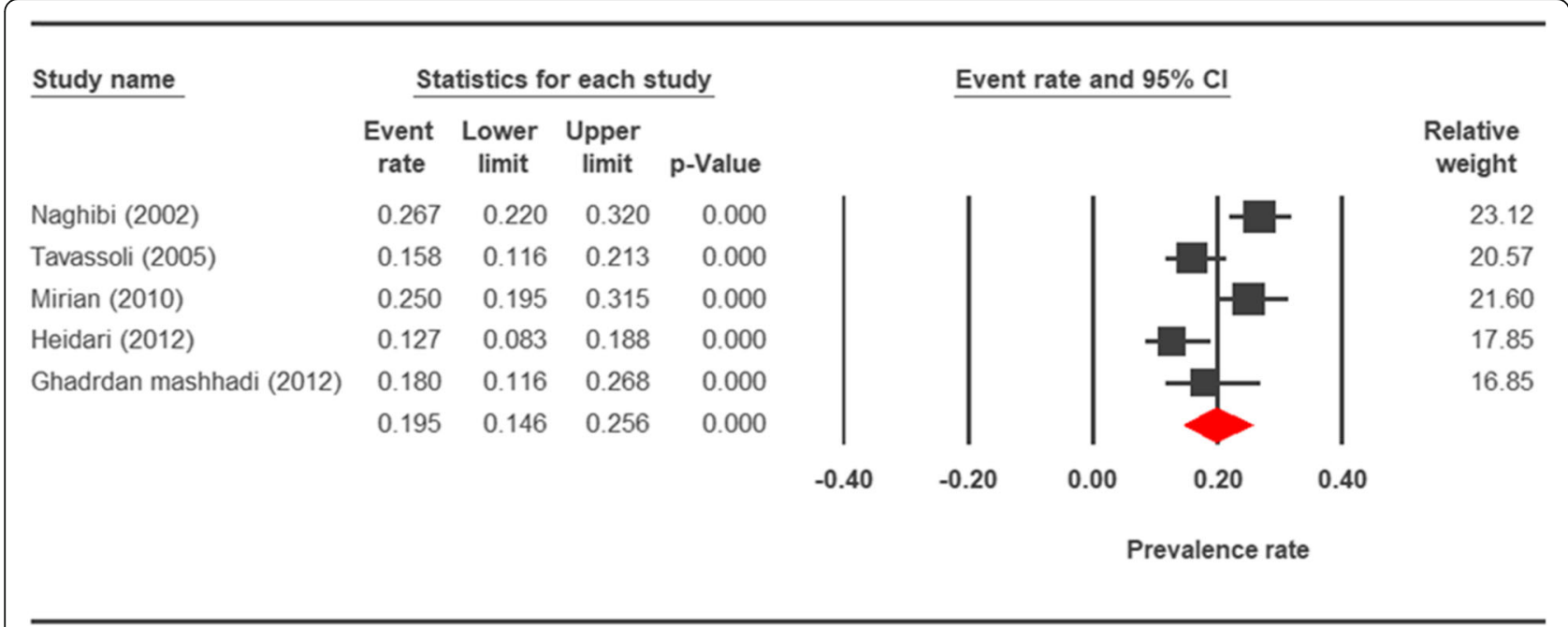

Fig. 3 Forest plot diagram showing the prevalence rate of Cryptosporidium infection in horses of Iran

the screened databases up to February 2018. Specifically, $62,124,174,62,543,10$, and 3820 studies collected from PubMed, Web of Science, Scopus, Scientific Information Database, Magiran, Science Direct, and Google Scholar, respectively. A total of 1933 duplicated records and 5 studies which were not original articles (i.e., letter, commentary, review) were screened out. Regarding the relevance of the title and abstract to the purpose of the study, 2857 irrelevant studies were excluded. Accordingly, 2757 studies were retrieved for further assessment. Altogether, 100 articles were selected for the meta-analysis study. The display process and literature search results were presented respectively in Fig. 1 and Table 1.

Within these 100 articles, 40, 16, 13, 10, 9, 7, and 5 studies were performed on cattle, birds, dogs, sheep, rodents, camels, and horses, respectively. The most frequent studies were performed on cattle and the least ones on horses. Considering the various projects in searching cryptosporidiosis on cattle in Iran, the distribution of positive cases relating to cattle is presented in Fig. 9. The quality assessment of studies using the guideline of the Newcastle Ottawa Scale showed that $27 \%, 65 \%$, and $8 \%$ of the studies have low, medium, and high quality, respectively.

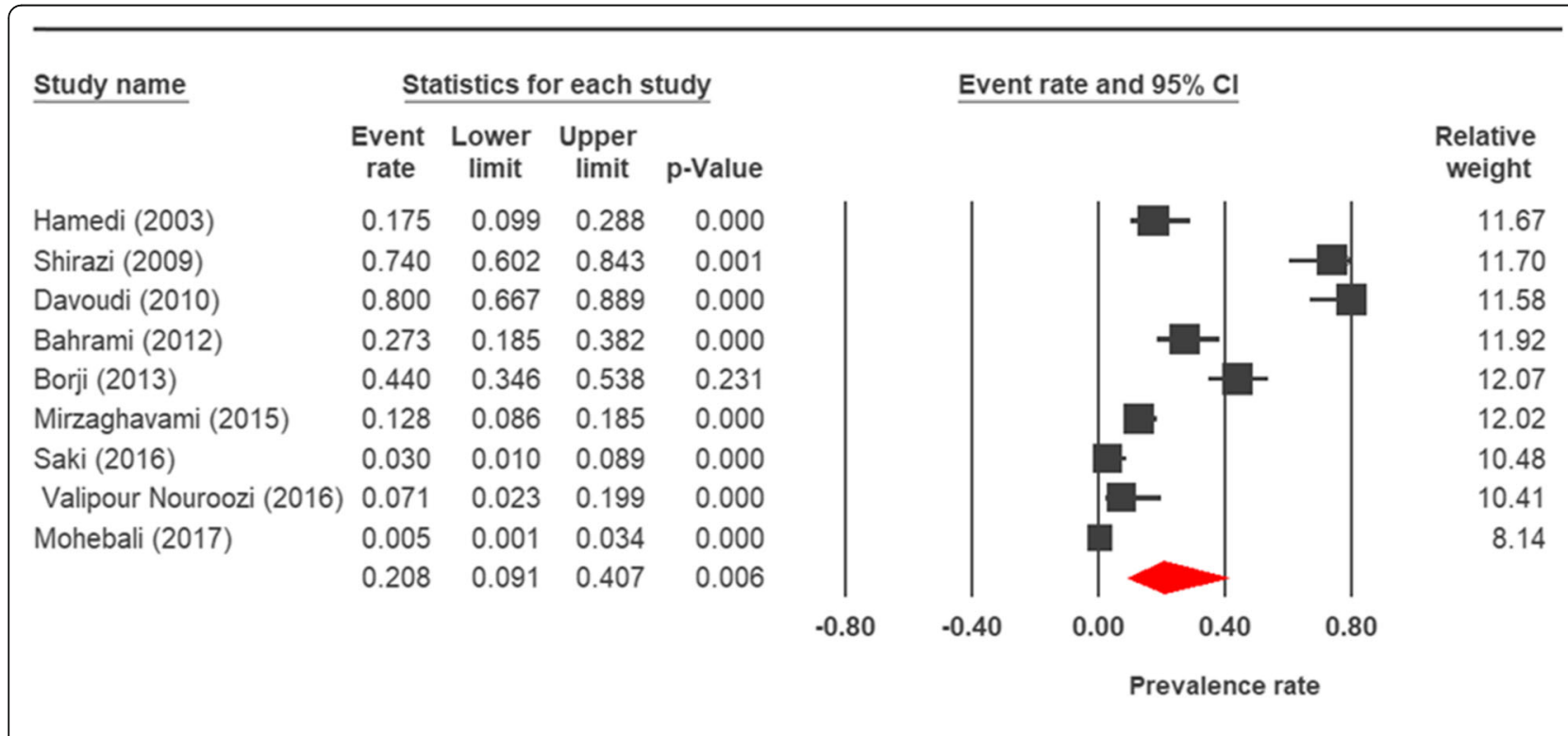

Fig. 4 Forest plot diagram showing the prevalence rate of Cryptosporidium infection in rodents of Iran 


\begin{tabular}{|c|c|c|c|c|c|c|c|c|}
\hline \multirow[t]{2}{*}{$\underline{\text { Study name }}$} & \multicolumn{4}{|c|}{ Statistics for each study } & & \multicolumn{3}{|c|}{ Event rate and $95 \% \mathrm{Cl}$} \\
\hline & $\begin{array}{l}\text { Event } \\
\text { rate }\end{array}$ & $\begin{array}{c}\text { Lower } \\
\text { limit }\end{array}$ & $\begin{array}{l}\text { Upper } \\
\text { limit }\end{array}$ & $\mathrm{p}$-Value & & & & $\begin{array}{c}\text { Relative } \\
\text { weight }\end{array}$ \\
\hline Borji (2009) & 0.020 & 0.009 & 0.043 & 0.000 & & & & 14.76 \\
\hline Razawi (2009) & 0.379 & 0.290 & 0.476 & 0.015 & & & & 16.38 \\
\hline Nazifi (2009) & 0.169 & 0.096 & 0.280 & 0.000 & & & & 15.48 \\
\hline Sazmand (2011) & 0.203 & 0.162 & 0.253 & 0.000 & & & & 16.68 \\
\hline Yakhchali (2012) & 0.100 & 0.063 & 0.155 & 0.000 & & & & 16.05 \\
\hline Radfar (2012) & 0.024 & 0.006 & 0.089 & 0.000 & & & & 11.67 \\
\hline \multirow[t]{4}{*}{ Shahraki (2015) } & 0.005 & 0.001 & 0.038 & 0.000 & & & & 8.97 \\
\hline & 0.084 & 0.038 & 0.178 & 0.000 & & & & \\
\hline & & & & & -0.40 & -0.20 & 0.00 & \\
\hline & & & & & & & Prevalenc & \\
\hline
\end{tabular}

Fig. 5 Forest plot diagram showing the prevalence rate of Cryptosporidium infection in camels of Iran

\section{Main analysis}

The prevalence rate of cryptosporidiosis within a 27-year period for birds, horses, rodents, camels, dogs, cattle, and sheep in Iran using the random effect model was estimated to be $7.5 \%$ (95\%, CI $=4.7 \%, 11.9 \%)$, $19.5 \%$ (95\%,
$\mathrm{CI}=14.6 \%, 25.6 \%), 20.8 \%(95 \%, \mathrm{CI}=9.1-40.7 \%), 8.4 \%$ (95\%, CI $=3.8 \%, 17.8 \%), 4.9 \%(95 \%, \mathrm{CI}=2.6 \%, 8.8 \%)$, $14.4 \%(95 \%, \mathrm{CI}=11 \%, 18.6 \%)$, and $9.1 \%(95 \%, \mathrm{CI}=$ $8.4 \%, 9.9 \%)$, respectively. The forest plot diagrams of the current study are shown in Figs. 2, 3, 4, 5, 6, 7, and 8.

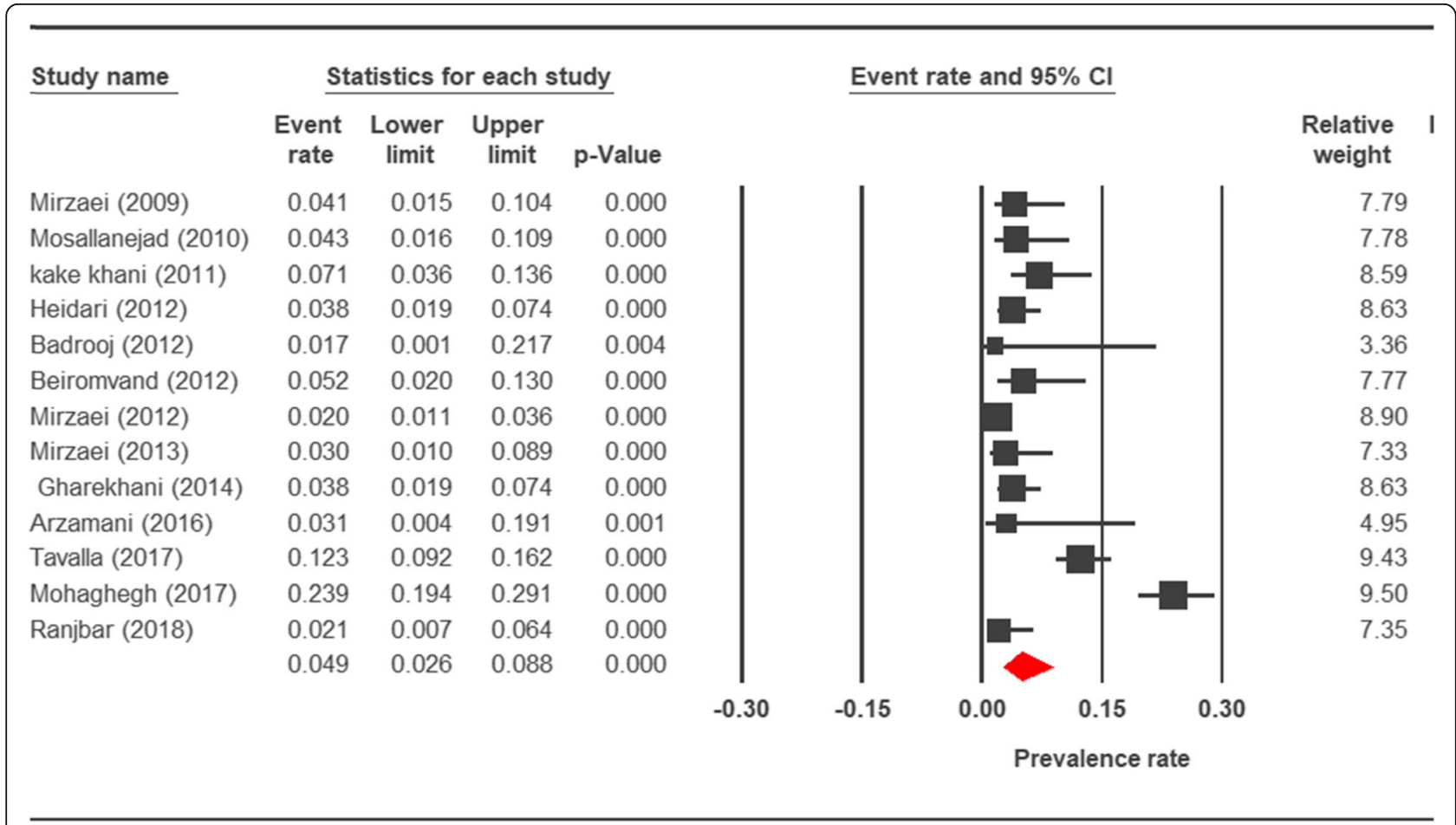

Fig. 6 Forest plot diagram showing the prevalence rate of Cryptosporidium infection in dogs of Iran 


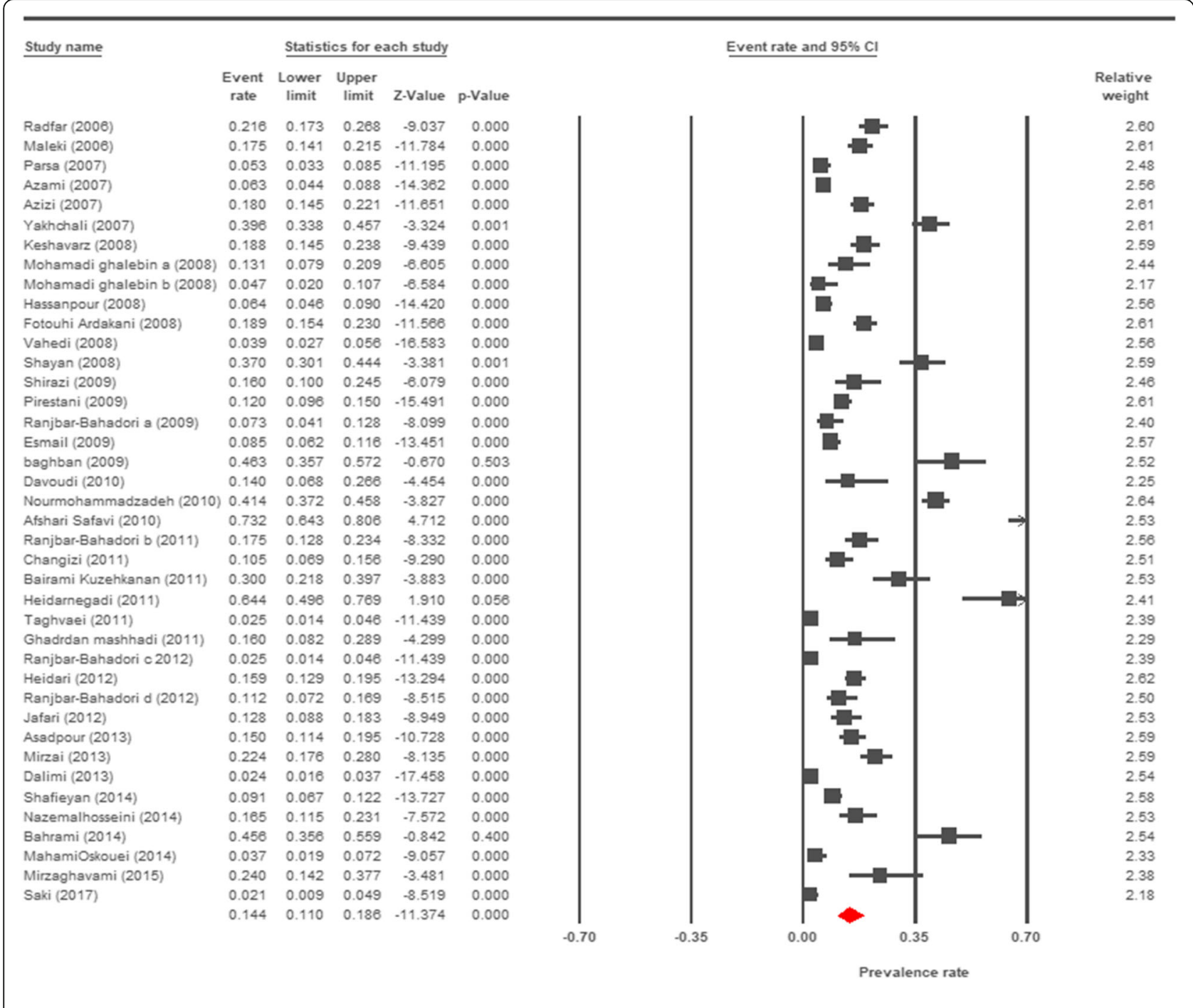

Fig. 7 Forest plot diagram showing the prevalence rate of Cryptosporidium infection in cattle of Iran

A wide variation was observed in the prevalence estimations among the various studies. The $Q$ statistic, $\mathrm{df}$, and $I^{2}$ were as follows: $26.63,15$, and $43.74 \%$ for birds; $15.15,8$, and $47.18 \%$ for rodents; $11.15,6$, and $46.17 \%$ for camels; $58.85,43$, and $26.93 \%$ for cattle; and 16.64 , 10 , and $39.93 \%$ for sheep, respectively. Low heterogeneity was reported in studies which were conducted on horses as well as the ones on dogs. The statistic factors ( $Q$ statistic, $\mathrm{df}$, and $I^{2}$ ) were $3.86,4,0.00 \%$ for horses and $6.07,12$, and $0.00 \%$ for dogs.

The prevalence rate of Cryptosporidium infection in cattle is shown in Fig. 9. The most positive cases of cryptosporidiosis were reported in cattle of West Azerbaijan, Tehran, Khuzestan, Chaharmahal and Bakhtiari, Kohgiluyeh and Boyer-Ahmad, and Kerman provinces. Considerable positivity rates of cryptosporidiosis in cattle were identified in Razavi Khorasan, South Khorasan, Semnan, Hamadan, Alborz, and East Azerbaijan provinces. There were no positive reports of cryptosporidiosis in cattle in other provinces.

\section{Discussion}

Cryptosporidiosis is one of the most important zoonotic diseases which is reported in humans and animals with a worldwide distribution in more than 106 countries and especially in developing countries [91, 92]. To the best of our knowledge, this is the first systematic review and meta-analyses on the prevalence of animal cryptosporidiosis in Iran.

The present study showed that the average prevalence rate of cryptosporidiosis in birds was $7.5 \%$ in Iran. Additionally, the prevalence rate of cryptosporidiosis in 


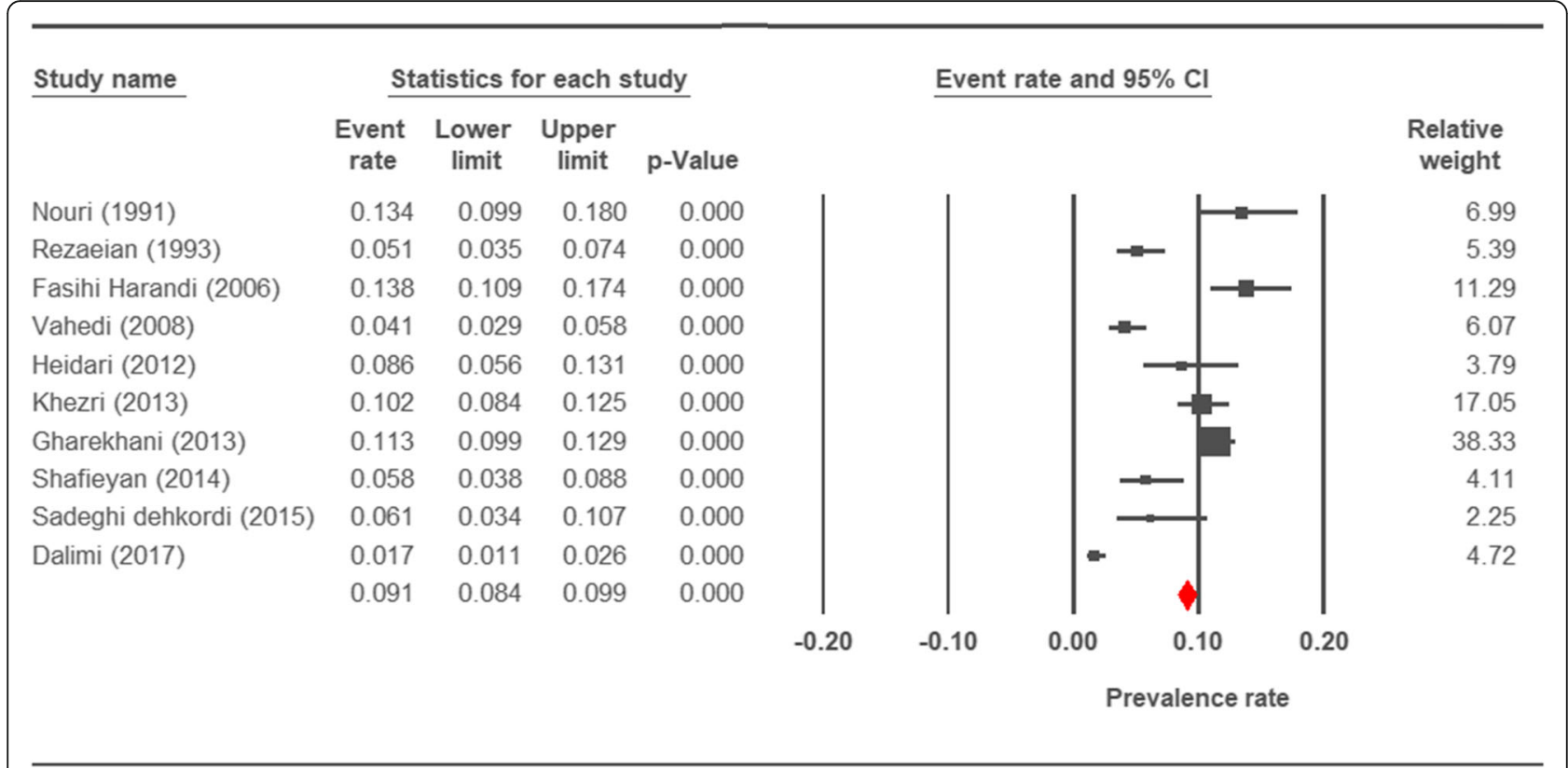

Fig. 8 Forest plot diagram showing the prevalence rate of Cryptosporidium infection in sheep of Iran

animals in Ahvaz, southwestern of Iran was reported as $50 \%$ [86] while it was shown that in Gilan, north of Iran, this rate was $17 \%$ [84]. In a study by Jasim and Marhoon, it has shown that in Iraq, which is a neighboring region of Iran, the cryptosporidiosis prevalence rate in wild and domestic birds was 58.1\% [93]. Even though this region is near the southwest of Iran, the prevalence was higher than in Iran. Moreover, a prevalence of $49 \%$ was shown in Mexico [94], and in Brazil, 76\% of birds were infected by Cryptosporidium [95]. Changes in the prevalence seen in various reports indicate that the probability of transmitting the parasite is higher among animals living together on farms and next to each other compared to other studies that have examined individual specimens.

Preventive efforts by Iranian authorities related to awareness of zoonotic diseases, control of stray dogs, and a low population of pet dogs have increased the possibility of transmission of the disease from livestock [96]. On the one hand, the stray dogs are the largest group of dogs in both rural and urban areas in Iran which usually become infected by roaming in human neighborhoods and feeding on contaminated residues. On the other hand, domestic dogs are not restricted to the limited area of houses or farms. Stray dogs are allowed to wander around, so it increases the risk of zoonotic infections in rural habitats. In this study, the overall prevalence of cryptosporidiosis between dogs was found to be $4.9 \%$ in Iran. There are various reports of cryptosporidiosis prevalence in the different geographical regions of Iran. Mohaghegh et al. reported a prevalence of $21.7 \%$ and $25.4 \%$ of cryptosporidiosis respectively in domestic and stray dogs of Kermanshah [61]. Furthermore, the 12.3\% prevalence rate of cryptosporidiosis in dogs was observed in Ahvaz [60]. These results are higher than the data which were obtained in other regions of Iran, specifically $5 \%$ in Chenaran, northeast of Iran [56]; 7\% in Ilam [97]; 2\% in Kerman, southeast of Iran [98]; $2.9 \%$ in Urmia, northwest of Iran [99]; 2.14\% in Isfahan, center of Iran [62]; and 3.8\% in Hamadan, west of Iran [17]. The high prevalence of cryptosporidiosis in some areas, for instance, Kermanshah Province, indicated that humans are at serious risk of Cryptosporidium infection. Furthermore, the infection can spread vastly and cause severe problems in the community.

Epidemiological studies on cryptosporidiosis infection indicated that the prevalence of Cryptosporidium species in dogs is very different in various countries changing from 0 to $52.7 \%$. These differences might be attributed to several factors, such as geographical area, sample size, keeping a dog, correlation with other hosts (such as goat, sheep, horse, cattle, and pig), different species of Cryptosporidium, and sampling procedures as well as diagnostic methods $[100,101]$. The current results imply that the prevalence rate of cryptosporidiosis in Iran is higher than in countries such as the Czech Republic with 1.4\% [102], Thailand with 2.1\% [103], Brazil with 2.4\% [104], Japan with 3.9\% [105], and Spain with 4.1\% [106], but lower than in Nigeria with 18.5\% [107] and Romania with 52.7\% [108].

Rodents could be potential reservoir hosts for zoonotic cryptosporidiosis. During extensive epidemiological studies that have been performed throughout the world, infection in rodents was highly varied from $7.6 \%$ in 


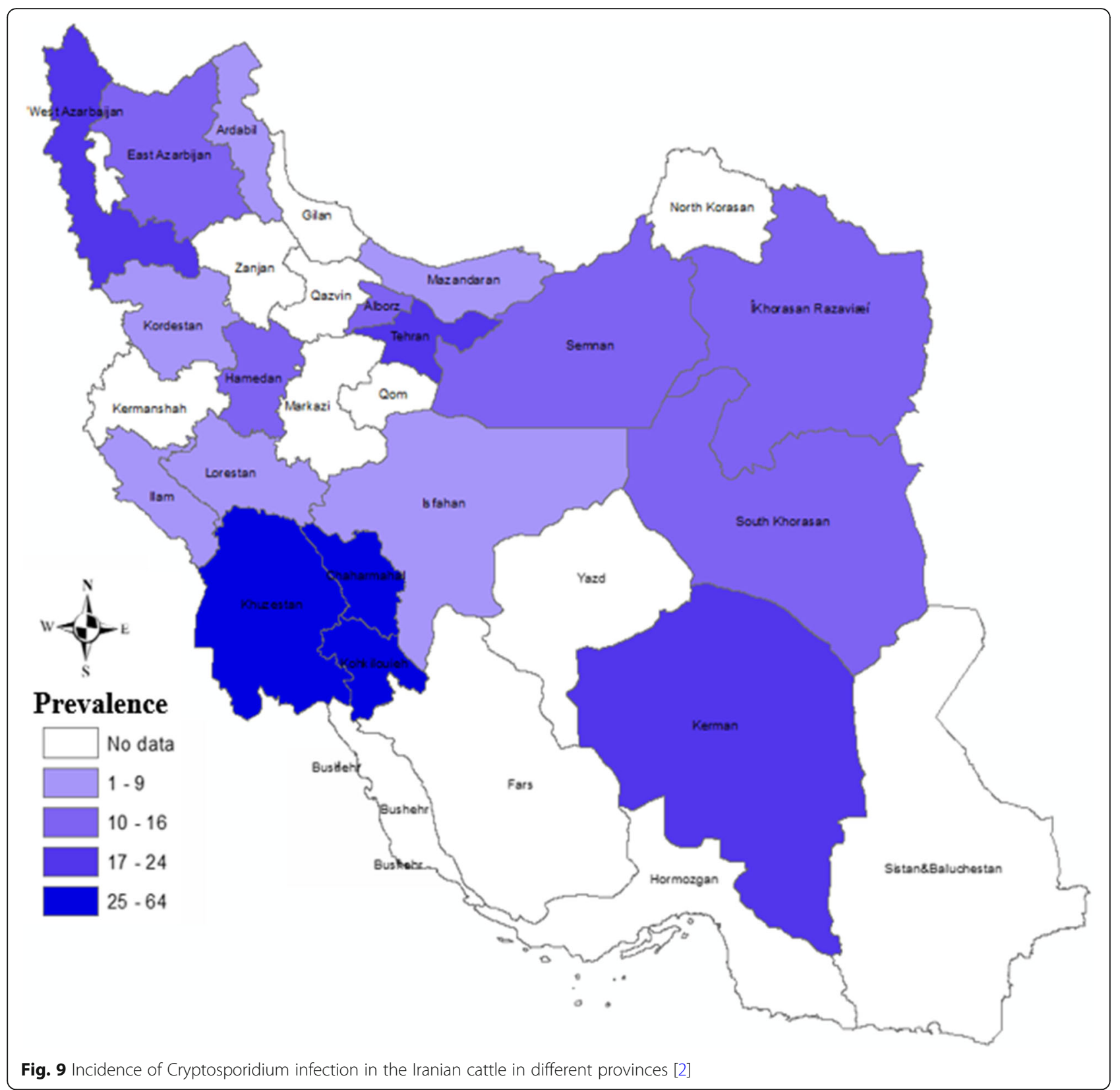

Maryland [109] to 63\% in United Kingdom [110]. Other studies showed different statistic in different countries. Specifically, 8.2\% in northern Australia [111], 11/5\% in China [112], 24.3\% in Italy [113], 25.8\% in Philippines [114], and 32.8\% in the United States of America [115] were reported. The average prevalence rate of cryptosporidiosis in rodents in Iran was estimated as $20.8 \%$ in this study. Similar studies in different geographical regions of Iran showed diverse range of prevalence. The frequency of rodent's cryptosporidiosis in Meshgin shahr, Tehran, Shooshtar, and Ahvaz was 0.5\% [75], 27.3 $\%$ [71], 7.1\% [74], and 3\% [1], respectively. In the parasite investigation of rodents of Mashhad, none resulted to be were contaminated $(0 \%)$ [72].

The average prevalence of cryptosporidiosis in sheep was found as $9.1 \%$. Prevalence of cryptosporidiosis was reported as $1.69 \%, 5.8 \% .6 .1 \%$ and $8.6 \%$ in Tehran [20], Lorestan [18], Sanandaj [19] and Hamadan [15], respectively. Majewska et al found similar results in the westcentral region of Poland (10.1\%) [116] but lower rates were detected in Australia (24.5\%) [117], and China (4.8\%) [118].

The prevalence rate of cryptosporidiosis in cattle was $1.5 \%$ in Japan [119], 35.7\% in Vietnam [120], 20.6\% in 
Turkey [121], 40.6\% in Canada [122], and $40.6 \%$ in the USA [123].

However, according to this systematic review and meta-analysis, the prevalence of cryptosporidiosis in cattle and calves was $14.4 \%$ in Iran, and the prevalence rate in various geographical regions was as follows: $2.1 \%$ in Ahvaz [73], 9.07\% in Lorestan [18], 16.45\% in Qazvin [26], 22.3\% in the city of Urmia [48], and $28.3 \%$ in the city of Mashhad [47]. Furthermore, our study showed that the prevalence rate of cryptosporidiosis in camels and horses was $8.4 \%$ and $19.5 \%$, respectively.

It was suggested in this study that the distribution of Cryptosporidium differs among geographical regions. Therefore, the study location might be one of the most determinant factors in cryptosporidiosis distribution. The highest prevalence rate (50\%) of cryptosporidiosis was observed in Khuzestan Province [86]. This high prevalence might be attributed to the high temperature and humidity of the southwestern regions of Iran as well as the people's lifestyle, who have a high level of seafood consumption compared to other regions. Additionally, the immigration of birds to the south of Khuzestan Province may transmit parasite protozoan infection.

\section{Conclusion}

The relatively high prevalence of cryptosporidiosis infection among animals in Iran, mostly among sheep, cattle, and calves, shows the enzootic status of cryptosporidiosis in the investigated areas and may be a threat to the inhabitants. Our data offer important information about the epidemiology of cryptosporidiosis among animals in Iran, which could be useful for managing and controlling programs for the disease. Further investigation and monitoring will be required to expand the surveillance and control policies in order to reduce the prevalence of Cryptosporidiosis among livestock and consequently decrease the economic damages and public health hazards in Iran.

\section{Supplementary Information}

The online version contains supplementary material available at https://doi. org/10.1186/s41182-020-00278-9.

Additional file 1. PRISMA Checklist.

\section{Abbreviations}

HIV: Human immunodeficiency viruses; Cl: Confidence interval

\section{Acknowledgements}

Not applicable.

\section{Authors' contributions}

This study was done by RG, ZK, SK, FFP, HS, NB, FE, and MMH. RG and MMH participated in the design of the study. Data collection was done by RG, FFP, and NB. Interpretation and manuscript preparation were conducted by $\mathrm{MMH}$ and RG. HS, RG, and MMH participated in the data editing. SK performed the statistical analysis. FE and ZK performed the coordination and helped with the drafting of the manuscript. The authors read and approved the final version of the manuscript.

Funding

Not funding

\section{Availability of data and materials}

Input data for the analyses are available from the corresponding author on request.

Ethics approval and consent to participate

Not applicable.

\section{Consent for publication}

Not applicable.

\section{Competing interests}

The authors declare that they have no competing interests.

\section{Author details}

${ }^{1}$ Department of Medical Parasitology and Mycology, School of Medicine, Hamadan University of Medical Sciences, Hamadan, Iran. ${ }^{2}$ Research Center for Health Sciences, Hamadan University of Medical Sciences, Hamadan, Iran. ${ }^{3}$ Department of Infectious Disease, School of Medicine, Arak University of Medical Sciences, Arak, Iran. ${ }^{4}$ Research and Technology, Hamadan University of Medical Sciences, Hamadan, Iran. ${ }^{5}$ Department of Parasitology and Mycology, School of Medicine, Arak University of Medical Sciences, Arak, Iran.

Received: 17 May 2020 Accepted: 29 October 2020

Published online: 05 December 2020

\section{References}

1. Saki J, Foroutan-Rad M, Asadpouri R. Molecular characterization of cryptosporidium spp. in wild rodents of southwestern Iran using $18 \mathrm{~s}$ rRNA gene nested-PCR-RFLP and sequencing techniques. J Trop Med. 2016;2016:1-6.

2. Mousavi-Hasanzadeh M, Sarmadian $H$, Ghasemikhah $R$, et al. Evaluation of toxoplasma gondii infection in western Iran: seroepidemiology and risk factors analysis. Trop Med Health. 2020;48:35.

3. Ghasemikhah R, Tabatabaiefar MA, Shariatzadeh SA, Shahbazi A, Hazratian T. A PCR-based molecular detection of strongyloides stercoralisin human stool samples from Tabriz city, Iran. Sci Pharm. 2017;85(2):17.

4. Mor SM, Tzipori S. Cryptosporidiosis in children in sub-Saharan Africa: a lingering challenge. Clin Infect Dis. 2008;47(7):915-21.

5. Tzipori S, Widmer G. A hundred-year retrospective on cryptosporidiosis. Trends Parasitol. 2008:24(4):184-9.

6. Dalimi A, Tahvildar F. Molecular study on Cryptosporidium andersoni strains isolated from sheep based on 18S rRNA gene. Infect Epidemiol Microbiol. 2017;3(3):100-3.

7. Mirian S, Asadi M, Ferdowsi H, Rezakhani A. A survey on horse cryptosporidial infection in Tehran Province. Arch Razi Inst. 2010;65(1):45-7.

8. Haghi MM, Etemadifar F, Fakhar M, Teshnizi SH, Soosaraei M, Shokri A, et al. Status of babesiosis among domestic herbivores in Iran: a systematic review and meta-analysis. Parasitol Res. 2017;116(4):1101-9.

9. Ranjbar R, Mirhendi H, Izadi M, Behrouz B, Mohammadi MR. Molecular identification of cryptosporidium spp. in Iranian dogs using seminested PCR: a first report. Vector Borne Zoonotic Dis. 2018;18(2):96-100.

10. Soosaraei M, Haghi MM, Etemadifar F, Fakhar M, Teshnizi SH, Hezarjaribi HZ, et al. Status of theileriosis among herbivores in Iran: a systematic review and meta-analysis. Vet World. 2018;11(3):332.

11. Moher D, Altman DG, Liberati A, Tetzlaff J. PRISMA statement. Epidemiology. 2011;1(22):128.

12. Wells GA, Shea B, O'Connell D, Peterson J, Welch V, Losos M, et al. Title of subordinate document. In: The Newcastle-Ottawa scale (NOS) for assessing the quality of nonrandomised studies in meta-analyses. Ontario: Ottawa Hospital Research Institute; 2009. http://www.ohri.ca/programs/clinical_ epidemiology/oxford.asp. Accessed 15 Jan 2009.

13. Nouri M, Karami M. Asymptomatic cryptosporidiosis in nomadic shepherds and their sheep. J Inf Secur. 1991;23(3):331-3.

14. Rezaeian M, Shahmoradi A, Dalimi A Cryptosporidum in sheep as a source for human infection. Med J Islam Repub Iran. 1993;6(4):273-4. 
15. Fasihi Harandi M, Fotouhi AR. Cryptosporidium infection of sheep and goats in Kerman: epidemiology and risk factor analysis. J Vet Res. 2008;63(1):47-51.

16. Vahedi N, Asl A, Saadat M. Primary research on gastro-intestinal cryptosporidium incidence rate in lambs and calves in Amol city. Iran J Vet Res. 2009;64(2):101-3.

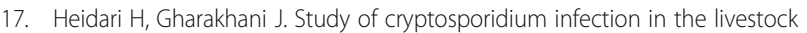
(cattle, sheep, dogs, fowls) and humans, in Hamadan city and its suburbs during 2006-2011. Avicenna J Clinical Med. 2012;19(3):67-74.

18. Khezri M, Khezri $O$. The prevalence of cryptosporidium spp. in lambs and goat kids in Kurdistan, Iran. Vet World. 2013;6(12):974.

19. Gharekhani J, Heidari H, Youssefi M. Prevalence of cryptosporidium infection in sheep in Iran. Turkiye Parazitol Derg. 2014;38(1):22.

20. Shafieyan H, Alborzi A, Hamidinejat H, Tabandeh MR, Hajikolaei MRH. Prevalence of cryptosporidium spp. in ruminants of Lorestan Province, Iran. J Parasit Dis. 2016:40(4):1165-9.

21. Sadeghi Dehkordi Z, Partoandazan A, Abdolmaleki N. Epidemiology of cryptosporidiosis in sheep of Sanandaj city. Zoonoses Res. 2016;2(1):25-9.

22. Radfar M, Molaei M, Baghbannejad A. Prevalence of cryptosporidium spp. oocysts in dairy calves in Kerman, southeastern Iran. IJVR. 2006;7(2):81-4.

23. Maleki S, Nayebzadeh $\mathrm{H}$. A survey on prevalence rate of cryptosporidiosis among diarrheic and healty cattle and calves in Khoram-Abad, Iran. J Vet Res. 2008;62(6):423-6.

24. Parsa A. Prevalence of Cryptosporidium muris-like (andersoni) infection in cattle and buffalo slaughtered in Tabriz area abattoir. Large Animal Clin Sci Res. 2007;1 (2):49-55 J. Vet. Sci.

25. Azami M. Prevalence of cryptosporidium infection in cattle in Isfahan, Iran. J Eukaryot Microbiol. 2007;54(1):100-2.

26. Azizi Hamidreza PM, Batol D, Hosein R. Prevalence of Cryptosporidium parvum parasites in dairy calves less than one year old. Iran J Vet Med. 2008;3(4):96-8

27. Yakhchali M, Gholami E. Prevalence of Eimeria and cryptosporidium spp in cattle of Sanandaj city (Kurdistan province), Iran. J Pajouhesh Sazandegi. 2008;87:81-7.

28. Keshavarz A, Haghighi A, Athari A, Kazemi B, Abadi A, Mojarad EN. Prevalence and molecular characterization of bovine cryptosporidium in Qazvin province, Iran. Vet Parasitol. 2009:160(3-4):316-8.

29. Mohammadi Ghalehbin B, Arzanlou M, Fallah E, Kazemi A, Asgharzadeh M. Molecular identification of cryptosporidium sp. in the cattle stool samples in Ardabil city, northwestern Iran. J Anim Vet Adv. 2008;7(3):246-50.

30. Hassanpour A. Prevalence of cryptosporidiosis in calves and humans to be in contact them in Tabriz area in Iran. Int J Infect Dis. 2008;12:e126.

31. Fotouhi Ardakani R, Fasihi Harandi M, Solayman Banai S, Kamyabi H, Atapour M, Sharifi I. Epidemiology of cryptosporidium infection of cattle in Kerman/Iran and molecular genotyping of some isolates. JKMU. 2015;15(4) 313-20.

32. Shayan P, Ebrahimzadeh E, Mokhber-Dezfouli M-R, Rahbari S. Recombinant Cryptosporidium parvum p23 as a target for the detection of cryptosporidium-specific antibody in calf sera. Parasitol Res. 2008;103(5): 1207-11.

33. Davoudi J, Shirazi S, Mostofi S, Vahidi MS. Evaluation of cryptosporidiosis in human, calf and mice around Tabriz. Vet Microbiol. 2010;6(1):75-9.

34. Pirestani M, Sadraei J, Dalimi AA. A survey on prevalence rate of cryptosporidial infection of farms in Shahriar County of Tehran and its hygienic importance in human. Vet Microbiol. 2010;85:44-53.

35. Ranjbar-Bahadori S, Sangsefidi $H$, Shemshadi B, Kashefinejad M. Cryptosporidiosis and its potential risk factors in children and calves in Babol, north of Iran. Trop Biomed. 2011;28(1):125-31.

36. Fallah $\mathrm{E}$, Ataallah $\mathrm{H}$. Prevalence of cryptosporidium oocysts from calves in Kurdistan Province, of Iran. J Parasit Dis. 2009:4(2):1-5.

37. Baghban Farshad MM. Frequency of cryptosporidium oocysts in the midst of calves (cryptosporidium spp. oocysts) under one month with diarrhea in Yasuj city. Vet J Islamic Azad University. 2010;6(3):17-22.

38. Nourmohammadzadeh F, Davoodi Y, Jamali R, Nowrouzian I. Epidemiological study on cryptosporidiosis in newborn calves in eastern Azarbaijan Province. J Vet Res. 2010;65(3):247-70.

39. Safavi Afshari E, Mohammadi GR, Naghibi A, Rad M. Prevalence of cryptosporidium spp. infection in some dairy herds of Mashhad (Iran) and its association with diarrhea in newborn calves. Comp Clin Pathol. 2011; 20(2):103-7.

40. Ranjbar-Bahadori S, Aliari M. Cryptosporidiosis and its risk factor in calves of husbandries around of Tehran, Iran. In: Animal hygiene and sustainable livestock production. Vienna: Proceedings of the XVth International Congress of the International Society for Animal Hygiene; 2011. https:// www.cabdirect.org/cabdirect/abstract/20113296231.

41. Changizi E, Salimi-Bejestani M, Vayeghan A. The cryptosporidium ryanae infection commence in Iranian cattle. J Vet Res. 2012;67(2):127-33.

42. Bairami Kuzehkanan A, Rezaeian M, Zeraati H, Mohebali M, Meamar AR, Babaei Z, et al. A sensitive and specific PCR based method for identification of cryptosporidium sp. using new primers from $18 \mathrm{~S}$ ribosomal RNA. Iran J Parasitol. 2011;6(4):1-7.

43. Heidarnegadi S, Mohebali M, Maraghi S, Babaei Z, Farnia S, Bairami A, et al. Cryptosporidium spp. infection in human and domestic animals. Iran J Parasitol. 2012;7(1):53.

44. Ranjbar S, Azizzadeh M, Taghvaei M. Study on the infection rate to cryptosporidium in suckling calves of Ghuchan district. Iran J Vet Res. 2013; 9(3):62-8.

45. Jafari MA, Ranjbar BS, Sheybani M. Investigating the possible role of protozoa (cryptosporidium, giardia coccidia) in diarrheal calves of Garmsar. Qom: First National Congress of Dairy, Dairy and Related Industries; 2012. http://meditech.ir/conference.National.Congress.of.dairy. cattle. Accessed 5 Dec 2019.

46. Heydari Heydar GJ. Frequency of cryptosporidium infection in human, animal and poultry in Hamadan and suburbs over the years 2007-2012. J Res Health Sci. 2013;19(3):67-74.

47. Ranjbar-Bahadon S, Toni S. Infection to cryptosporidium in diarrheic calves: a provincial study in southern Khorasan. J Vet Res. 2013;68(1):13-9.

48. Jafari R, Maghsood AH, Fallah M. Prevalence of cryptosporidium infection among livestock and humans in contact with livestock in Hamadan district, Iran, 2012. J Res Health Sci. 2012;29(13):86-9.

49. Asadpour M, Razmi G, Mohhammadi G, Naghibi A. Prevalence and molecular identification of cryptosporidium spp. in pre-weaned dairy calves in Mashhad area, Khorasan Razavi Province, Iran. Iran J Parasitol. 2013;8(4):601.

50. Mirzai Y, Yakhchali M, Mardani K. Cryptosporidium parvum and Cryptosporidium andersoni infection in naturally infected cattle of Northwest Iran. Vet Res Forum. 2014;5(1):55-60.

51. Dalimi A, Tahvildar F, Kazemi B. Molecular identification of Cryptosporidium andersoni in Shahriar calves. Vet Research Biol Pro. 2015:28(2):24-30.

52. Mojarad N, Nejad MR, Keshavarz A, Taghipour N, Lamuki RM, Salehi A, et al. Molecular characterization of bovine cryptosporidium using cryptosporidium oocyst wall protein (COWP) gene. J Paramed Sci. 2014; 5(3):17-20.

53. Bahrami S, Alborzi R, Molayan PH, Purbaram S, Mousavi B. Prevalence of cryptosporidium spp. infection and its association with diarrhea in buffalo calves in Khuzestan, a southwestern province of Iran. Buffalo Bull. 2014;33(4):393-9.

54. Oskouei MM, Fallah E, Ahmadi M, Safaiyan A, Bakhtiyari S, Naserifar R, et al. Molecular and parasitological study of cryptosporidium isolates from cattle in Ilam, west of Iran. Iran J Parasitol. 2014;9(3):435.

55. Mirzaghavami M, Sadraei J, Forouzandeh M. Detection of cryptosporidium spp. in free ranging animals of Tehran, Iran. J Parasit Dis. 2016:40(4):1528-31.

56. Mosallanejad B, Hamidinejat H, Avizeh R, Ghorbanpoor Najafabadi M, Razi JM. Antigenic detection of Cryptosporidium parvum in urban and rural dogs in Ahvaz district, outhwestern Iran. Iran J Vet Res. 2010;11(3):273-8.

57. Kakekhani S, Bahrami AM, Ahmady Asabchin S, Doosti A. A study on protozoan infections (giardia, Entamoeba, Isospora and cryptosporidium) in stray dogs in llam Province. JVCP. 2011:5(3):1325-30.

58. Badrooj A, Asgari G, Hatam G. Molecular survey on cryptosporidiosis in stray dogs and cats in shiraz city during 2011-2012; 2012. http://elib.sums.ac.ir/ cgi-bin/koha/opac-main.pl. Accessed 20 Dec 2019.

59. Beiromvand M, Akhlaghi L, Massom SHF, Meamar AR, Motevalian A, Oormazdi $\mathrm{H}$, et al. Prevalence of zoonotic intestinal parasites in domestic and stray dogs in a rural area of Iran. Prev Vet Med. 2013;109(1-2):162-7.

60. Mirzaei M, Fooladi M. Coproscopy survey of gastrointestinal parasites in owned dogs of Kerman city, Iran. Vet Ital. 2013;49:309-13.

61. Gharekhani J. Study on gastrointestinal zoonotic parasites in pet dogs in Western Iran. Turkiye Parazitol Derg. 2014;38(3):172

62. Arzamani K, Rouhani S, Mousazadeh-Mojarrad A, Sedeghi S, Rostami M, Raeghi S. Identification of zoonotic parasites isolated from stray dogs in Bojnurd County located in north-east of Iran. NBM. 2016:4(4):185-8.

63. Tavalla M, Kord E, Abdizadeh R, Asgarian F. Molecular study of cryptosporidium spp. in dogs from southwest of Iran. Jundishapur J Microbiol. 2017;10(4):e43412. 
64. Mohaghegh M, Vafaei M, Ghomashlooyan M, Azami M, Falahati M, Azadi $Y$, et al. A wide diversity of zoonotic intestinal parasites in domestic and stray dogs in rural areas of Kermanshah Province, Iran. Trop Biomed. 2018;35(1):82-90.

65. Borji H, Razmi G, Movassaghi AR, Naghibi AG, Maleki M. Prevalence of cryptosporidium and Eimeria infections in dromedary (Camelus dromedarius) in abattoir of Mashhad, Iran. J Camel Pract Res. 2009;16(2): 167-70.

66. Behzadi M, Razavi S, Yazdanpoor H, Mirzaei A, Tamadon A, Gandomani MJ. Epidemiology of cryptosporidium infection in ostriches (Struthio camelus) in Iran. Bulg J Vet Med. 2009;12(1):55-61.

67. Nazifi S, Behzadi M, Haddadi S, Jahromi AR, Mehrshad S, Tamadon A. Prevalence of cryptosporidium isolated from dromedary camels (Camelus dromedarius) in Qeshm Island, southern Iran. Comp Clin Pathol. 2010;19(3):311-4

68. Sazmand A, Rasooli A, Nouri M, Hamidinejat H, Hekmatimoghaddam S Prevalence of cryptosporidium spp. in camels and involved people in Yazd Province, Iran. Iran J Parasitol. 2012;7(1):80-4.

69. Yakhchali M, Moradi T. Prevalence of cryptosporidium-like infection in onehumped camels (Camelus dromedarius) of northwestern Iran. Parasite: SFP. 2012;19(1):71.

70. Radfar MH, Gowhari MA, Khalili M. Comparison of capture ELISA and modified Ziehl-Neelsen for detection of Cryptosporidium parvum in feces of camel (Camelus dromedarius) in Iran. Sci Parasito. 2013;14(3):147-52.

71. Shahraki F, Rasekh M. Prevalence of Cryptosporidium parvum in the cities of Sistan region by ELISA and evaluation of risk factors of season, age and sex; 2016. https://ganj.irandoc.ac.ir. Accessed 29 Feb 2019.

72. Hamedi HM, Soleymani M. Parasites of the rodent and blood vessels of the head and neck of the abbey. HMJ. 2004;7(3):123-7

73. Shirazi S, Mirsamadi N, Shahbazi P. Evaluation of cryptosporidiosis in human, calf and mice around Tabriz. Vet J Islamic Azad Uni. 2010;6(3):53-8.

74. Bahrami F, Sadraei J, Frozandeh M. Molecular characterization of cryptosporidium spp. in wild rats of Tehran, Iran using $18 \mathrm{~s}$ rRNA gene and PCR_RFLP method. Jundishapur J Microbiol. 2012;3(5):486.

75. Borji H, Khoshnegah J, Razmi G, Amini H, Shariatzadeh M. A survey on intestinal parasites of golden hamster (Mesocricetus auratus) in the northeast of Iran. J Parasit Dis. 2014;38(3):265-8.

76. Valipour NR. Prevalence of cryptosporidium in wild brown rat (Rattus norvegicus) population at Shoushtar, Iran. Int Electron J Med. 2016;5(1):18-22.

77. Mohebali M, Zarei Z, Khanaliha K, Kia EB, Motavalli-Haghi A, Davoodi J, et al. Natural intestinal protozoa in rodents (Rodentia: Gerbillinae, Murinae, Cricetinae) in northwestern Iran. Iran J Parasitol. 2017;12(3):382.

78. Banani M, Dadras H, Moazeni Joula G, Houshmandrad P. Serologic incidence of cryptosporidial infection in broiler flocks in Shiraz, Iran. Arch Razi Ins. 2000;51:95-102.

79. Mirzaei M, Mohammadi V, Fotouhi A. Prevalence of intestinal cryptosporidium infection in Kerman pigeons. Sci Res Iranian Vet J. 2008; 4(2):115-21.

80. Norolahi Fard F, Asl N, Rezaei Seghinsara H. Prevalence of intestinal cryptosporidiosis in pigeons in Mashhad. Iranian J Vet Clin Sci. 2011;4(1):21-8.

81. Shemshadi B, Bahadori SR, Mozafari A. Study on cryptosporidiosis incidence in broilers in Garmsar region, Iran. Comp Clin Pathol. 2011;20(2):143-9.

82. Haghbin N, Mousavi S, Ranjbar B, Mohammadi M, Hoseini S. Frequency of cryptosporidium infection in broiler breeding flock of Ghaemshahr. Vet Res (Ghamsar Branch). 2011;7(1):1-5.

83. Radfar MH, Asl EN, Seghinsara HR, Dehaghi MM, Fathi S. Biodiversity and prevalence of parasites of domestic pigeons (Columba livia domestica) in a selected semiarid zone of South Khorasan, Iran. Tropical Anim Heaith Pro. 2012:44(2):225-9.

84. Hamidinejat $H$, Jalali MHR, Jafari RA, Nourmohammadi K. Molecular determination and genotyping of cryptosporidium spp. in fecal and respiratory samples of industrial poultry in Iran. Asian Pac J Trop Med. 2014; 7(7):517-20

85. Hashemzadeh Farhang $\mathrm{H}$, Bahavarnia SP Sr. Investigation of cryptosporidium parasitic infection in native poultry around Tabriz city. Vet Clin Pathol. 2015;8(3):588-95.

86. Hashemzadeh F, Shahbazi P, Jafari R. Survey of cryptosporidium parasite infection in poultry farms around Tabriz. Vet Clin Pathol. 2014;8(1):411-6.

87. Shemshadi B, Ranjbar-bahadori S, Delfan-abazari M. Prevalence and intensity of parasitic infection in domestic ducks (Anas platyrhynchas) in Gilan Province, northern Iran. Comp Clin Pathol. 2017;26(1):165-7.
88. Soltanialvar Masood GZ. Frequency of infection of native turkeys with Cryptosporidum parasites in Dezful city. The first National Conference on common diseases between humans and animals. JVH. 2017;3:1-7.

89. Larki S, Alborzi A, Chegini R, Amiri R. A preliminary survey on gastrointestinal parasites of domestic ducks in Ahvaz, Southwest Iran. Iran J Parasitol. 2018;13(1):137.

90. Naghibi A, Vahedi H. Prevalence of cryptosporidial infection in horse and man in Mashhad, Iran. Arch Razi Inst. 2002:54:101-6.

91. Tavasouli M, Sodagar S, Soltan A. A survey on cryptosporidial infection in horse in Urmia area, northwestern Iran. Iran J Vet Res. 2007:8(1):86-90.

92. Ghadrdan A, Hamidienjat $H$, Alizadehnia P. A survey on frequency of equine cryptosporidiosis in Ahvaz. Vet Clin Path Tabriz. 2013;6(4):1723-7.

93. Jasim G, Marhoon A. Prevalence and molecular analysis of cryptosporidium spp isolated from wild and domestic birds. Acta Parasitol. 2015;6(2):65-70.

94. Kuhn RC, Rock CM, Oshima KH. Occurrence of cryptosporidium and giardia in wild ducks along the Rio Grande River valley in southern New Mexico. Appl Environ Microbiol. 2002;68(1):161-5.

95. Bomfim T, Gomes R, Huber F, Couto M. The importance of poultry in environmental dissemination of cryptosporidium spp. Open Vet Sci J. 2013; $7(1): 12-7$

96. Traub RJ, Robertson ID, Irwin PJ, Mencke N, Thompson RA. Canine gastrointestinal parasitic zoonoses in India. Trends Parasitol. 2005;21(1):42-8.

97. Bahrami A, Doosti A, Nahravanian H, Noorian A, Asbchin S. Epidemiological survey of gastro-intestinal parasites in stray dogs and cats. Aust J Basic Appl Sci. 2011;5:1944-8.

98. Mirzaei M, Fooladi M. Prevalence of intestinal helminthes in owned dogs in Kerman city, Iran. Asian Pac J Trop Med. 2012;5(9):735-7.

99. Tavassoli M, Javadi S, Soltanalinejad F, Rosouli S, Etminanfar R. Gastrointestinal parasites of pet dogs in Urmia city. Vet J Pajouhesh Sazandegi. 2010:87:18-24.

100. Simpson J, Burnie A, Miles R, Scott J, Lindsay D. Prevalence of giardia and cryptosporidium infection in dogs in Edinburgh. Vet Rec. 1988;123(17):445.

101. Batchelor D, Tzannes S, Graham P, Wastling J, Pinchbeck G, German A. Detection of endoparasites with zoonotic potential in dogs with gastrointestinal disease in the UK. Transbound Emerg Dis. 2008;55(2):99-104

102. Dubná S, Langrová I, Nápravník J, Jankovská I, Vadlejch J, Pekár S, et al. The prevalence of intestinal parasites in dogs from Prague, rural areas, and shelters of the Czech Republic. Vet Parasitol. 2007;145(1-2):120-8.

103. Koompapong K, Mori $H$, Thammasonthijarern N, Prasertbun R, Pintong A-R, Popruk S, et al. Molecular identification of cryptosporidium spp. in seagulls, pigeons, dogs, and cats in Thailand. Parasite. 2014;21:52.

104. Huber F, Bomfim T, Gomes R. Comparison between natural infection by cryptosporidium sp., giardia sp. in dogs in two living situations in the west zone of the municipality of Rio de Janeiro. Vet Parasitol. 2005;130(1-2):69-72.

105. Yoshiuchi R, Matsubayashi M, Kimata I, Furuya M, Tani H, Sasai K. Survey and molecular characterization of cryptosporidium and giardia spp. in owned companion animal, dogs and cats, in Japan. Vet Parasitol. 2010;174(3-4):313-6.

106. Gil H, Cano L, de Lucio A, Bailo B, de Mingo MH, Cardona GA, et al. Detection and molecular diversity of giardia duodenalis and cryptosporidium spp. in sheltered dogs and cats in northern Spain. Infect Genet Evol. 2017;50:62-9.

107. Olabanji GM, Maikai BV, Otolorin GR. Prevalence and risk factors associated with faecal shedding of cryptosporidium oocysts in dogs in the Federal Capital Territory, Abuja, Nigeria. Vet Med Int. 2016;2016:1-7.

108. Titilincu A, Mircean V, Achelaritei D, Cozma V. Prevalence of cryptosporidium spp. in asymptomatic dogs by ELISA and risk factors associated with infection. Lucrari Stiintifice. 2010;43(1):7-12.

109. Zhou L, Fayer R, Trout JM, Ryan UM, Schaefer FW, Xiao L. Genotypes of cryptosporidium species infecting fur-bearing mammals differ from those of species infecting humans. Appl Environ Microbiol. 2004;70(12):7574-7.

110. Webster JP, Macdonald DW. Cryptosporidiosis reservoir in wild brown rats (Rattus norvegicus) in the UK. Epidemiol Infect. 1995;115(1):207-9.

111. Paparini A, Jackson B, Ward S, Young S, Ryan UM. Multiple cryptosporidium genotypes detected in wild black rats (Rattus rattus) from northern Australia. Exp Parasitol. 2012;131(4):404-12.

112. Lv C, Zhang L, Wang R, Jian F, Zhang S, Ning C, et al. Cryptosporidium spp. in wild, laboratory, and pet rodents in China: prevalence and molecular characterization. Appl Environ Microbiol. 2009;75(24):7692-9.

113. Kvác M, Hofmannová L, Bertolino S, Wauters L, Tosi G, Modrý D. Natural infection with two genotypes of cryptosporidium in red squirrels (Sciurus vulgaris) in Italy. Folia Parasitol. 2008;55(2):95. 
114. Ng-Hublin JS, Singleton GR, Ryan U. Molecular characterization of cryptosporidium spp. from wild rats and mice from rural communities in the Philippines. Infect Genet Evol. 2013;16:5-12.

115. Feng Y, Alderisio KA, Yang W, Blancero LA, Kuhne WG, Nadareski CA, et al. Cryptosporidium genotypes in wild life from a New York watershed. Appl Environ Microbiol. 2007;73(20):6475-83.

116. Majewska AC, Werner A, Sulima P, Luty T. Prevalence of cryptosporidium in sheep and goats bred on five farms in west-central region of Poland. Vet Parasitol. 2000;89(4):269-75.

117. Yang R, Jacobson C, Gordon C, Ryan U. Prevalence and molecular characterisation of cryptosporidium and giardia species in pre-weaned sheep in Australia. Vet Parasitol. 2009;161(1-2):19-24.

118. Wang Y, Feng Y, Cui B, Jian F, Ning C, Wang R, et al. Cenvine genotype is the major cryptosporidium genotype in sheep in China. Parasitol Res. 2010;106(2):341.

119. Koyama Y, Satoh M, Maekawa K, Hikosaka K, Nakai Y. Isolation of Cryptosporidium andersoni Kawatabi type in a slaughterhouse in the northern island of Japan. Vet Parasitol. 2005;130(3-4):323-6.

120. Nguyen ST, Nguyen DT, Le DQ, Le Hua LN, Van Nguyen T, Honma H, et al. Prevalence and first genetic identification of cryptosporidium spp. in cattle in Central Viet Nam. Vet Parasitol. 2007;150(4):357-61.

121. Sevinc F, Irmak K, MSevinc M. The prevalence of Cryptosporidium parvum infection in the diarrhoiec and non-diarrhoeic calves. Rev Med Vet. 2003; 154(5):357-62

122. Trotz-Williams L, Martin D, Gatei W, Cama V, Peregrine A, Martin S, et al. Genotype and subtype analyses of cryptosporidium isolates from dairy calves and humans in Ontario. Parasitol Res. 2006;99(4):346-52.

123. Fayer R, Santín M, Xiao L. Cryptosporidium bovis n. sp. (Apicomplexa: Cryptosporidiidae) in cattle (Bos taurus). J Parasitol. 2005;91:624-9.

\section{Publisher's Note}

Springer Nature remains neutral with regard to jurisdictional claims in published maps and institutional affiliations.

Ready to submit your research? Choose BMC and benefit from:

- fast, convenient online submission

- thorough peer review by experienced researchers in your field

- rapid publication on acceptance

- support for research data, including large and complex data types

- gold Open Access which fosters wider collaboration and increased citations

- maximum visibility for your research: over $100 \mathrm{M}$ website views per year

At BMC, research is always in progress.

Learn more biomedcentral.com/submissions 